Published as: I. Zelenika-Zovko and J. M. Pearce, "Diverting Indirect Subsidies from the Nuclear Industry to the Photovoltaic Industry:

Energy and Economic Returns”, Energy Policy 39, pp. 2626-2632 (2011). DOI: http://dx.doi.org/10.1016/j.enpol.2011.02.031

\title{
Diverting Indirect Subsidies from the Nuclear Industry to the Photovoltaic Industry: Energy and Financial Returns
}

\author{
I. Zelenika-Zovko ${ }^{1}$ and J. M. Pearce ${ }^{1,2^{*}}$ \\ 1. School of Environmental Studies, Queen's University \\ 2. Department of Mechanical and Materials Engineering, Queen's University \\ * Corresponding author: 60 Union Street, Kingston, Ontario, K7L 3N6 Canada, 613-533-3369, \\ pearce@me.queensu.ca
}

\begin{abstract}
Nuclear power and solar photovoltaic energy conversion often compete for policy support, which governs economic viability. This paper compares current subsidization of the nuclear industry with providing equivalent support to manufacturing photovoltaic modules. Current U.S. indirect nuclear insurance subsidies are reviewed and the power, energy and financial outcomes of this indirect subsidy are compared to equivalent amounts for indirect subsidies (loan guarantees) for photovoltaic manufacturing using a model that holds economic values constant for clarity. The preliminary analysis indicates that if only this one relatively ignored indirect subsidy for nuclear power was diverted to photovoltaic manufacturing, it would result in more installed power and more energy produced by midcentury. By 2110 cumulative electricity output of solar would provide an additional 48,600TW-hrs over nuclear worth $\$ 5.3$ trillion. The results clearly show that not only does the indirect insurance liability subsidy play a significant factor for nuclear industry, but also how the transfer of such an indirect subsidy from the nuclear to photovoltaic industry would result in more energy over the life cycle of the technologies.
\end{abstract}

Keywords: nuclear energy; nuclear insurance subsidy; photovoltaic energy; indirect subsidy

\section{Introduction}

As energy demand continues to grow so does the debate over the energy supply of the future. This debate is complicated by ongoing global climate destabilization as a result of green house gas (GHG) emissions largely from burning fossil fuels for energy (IPCC, 2008). These scientific findings have catalyzed commitments by many industrialized countries to curb GHG emissions, which in turn have created an enormous need for large-scale sources of energy alternatives to fossil fuels (Hoffer et al, 2002; Kutscher, 2007). As the deliberation over the future of energy supply intensifies, nuclear technology is often pitted against renewable sources such as solar photovoltaic (PV) technology (Etzkowitz, 1984; Barnham, et al., 2006). The argument is amplified through comparisons of energy capacity (WEC, 2004), life cycle GHG emissions (Fthenakis and Kim, 2007; Kenny, et al., 2010; Pearce, 2008a) and economic performance (McLellan, 2008). 
Published as: I. Zelenika-Zovko and J. M. Pearce, "Diverting Indirect Subsidies from the Nuclear Industry to the Photovoltaic Industry: Energy and Economic Returns”, Energy Policy 39, pp. 2626-2632 (2011). DOI: http://dx.doi.org/10.1016/j.enpol.2011.02.031

The economic arguments in particular are distorted by subsidies, and it is important to note that all forms of energy received and still receive subsidies, the vast majority of which go to fossil fuels (IEA, 2010). Current PV system prices must be subsidized in some way before economies of scale drive PV prices down to economically competitive levels with the subsidized fossil fuels (Pearce, 2008b). However, while nuclear industries in the United States (U.S.) have been subsidized since their inception, nuclear power is still often perceived and advertised as an inexpensive source of electricity (Brown, 2006). Despite the low GHG emissions claims, the recent most comprehensive analysis of the viability of nuclear power generation at MIT concluded that unless issues related to "high construction costs, safety, potential proliferation security risks, as well as challenges in long-term management of nuclear wastes" are resolved, "nuclear power will diminish as a practical and timely option for deployment at a scale that would constitute a material contribution to climate change risk mitigation" (Deutch, et al., 2009). Similar conclusions have been reported by other analysts (Cooper, 2009; Blackburn and Cunningham, 2010). Nevertheless there is still an aggressive marketing campaign underway by the nuclear industry for a 'Nuclear Renaissance' in both Canada and the U.S. (AECL, 2009; Bouw, 2010; Ling, 2010).

While it is well established that nuclear power is a heavily subsidized industry, and has been so since the end of WWII (Goldberg, 2000; Martin and Paerson, 2001; Slavin, 2009), one aspect of nuclear subsidization is rarely included in analysis because it is difficult to quantify: the indirect insurance liability subsidy. Essentially an artificial cap on insurance liability reduces the costs of nuclear energy and represents an indirect subsidy. As indirect subsidies have no upfront costs for governments they are particularly attractive in the face of escalating energy demands and the need to radically reduce GHG emissions. However, since no nuclear power plants could be built without government backing for the liability damages (Reuters, 2001) it is clear that this subsidy should be counted into the equation of cost-analysis of nuclear energy.

Indirect support from governments is also possible for other energy sources, and it has been shown that the photovoltaic industry could benefit from a similar subsidy in the form of loan guarantees for large-scale photovoltaic manufacturing plants (an arrangement with the added benefit of attractive returns for participating governments) (Branker and Pearce, 2010). Until very recently meaningful comparisons of solar PV and nuclear power were not possible because there was no PV manufacturing capacity on a scale that could compete. Now the technical evolution of PV is advanced enough to produce fabrication facilities at the GigaWatt scale. This change demands a reassessment, which is provided here. This paper thus compares the energy and financial return for providing identically-sized indirect subsidies to the nuclear and photovoltaic industries in the form of the insurance liability subsidy for the nuclear industry and the manufacturing loan guarantee for the photovoltaic industry. First, the general role and scope of indirect government subsidies are analyzed and the magnitude of nuclear insurance liability within the United States is quantified. Then the potential power and energy outputs are quantified and compared for an indirect subsidy in the current U.S. nuclear industry to an identical one in solar photovoltaic manufacturing. Then the potential power, energy and financial returns are quantified for a transfer of the indirect nuclear insurance subsidy to the PV industry. These results are discussed and conclusions drawn about the effect of these policies. 
Published as: I. Zelenika-Zovko and J. M. Pearce, "Diverting Indirect Subsidies from the Nuclear Industry to the Photovoltaic Industry: Energy and Economic Returns”, Energy Policy 39, pp. 2626-2632 (2011). DOI: http://dx.doi.org/10.1016/j.enpol.2011.02.031

\section{Indirect Nuclear Insurance Subsidy}

Generally in economics, a subsidy is a payment made by the government which forms a wedge between the price consumers pay and the real costs incurred by producers, so that price remains less than marginal cost (Tokarickm, 1996). In the case of nuclear insurance liability, because there is no payment unless a catastrophe occurs, there is no direct subsidy or actual money exchanging hands, but there is an indirect subsidy because no nuclear power plant (NPP) could be built without a government guarantee to cover its full accident liability. In other words, no NPP could be built if the owner had to pay for the full cost of liability insurance. The U.S. Nuclear Regulatory Commission (USNRC) concluded the liability limits provided by nuclear insurance were significant as to constitute a subsidy, but a quantification of the amount was not attempted (1983). While low-probability risks are familiar to many disciplines such as structural and safety engineering, insurance, financial and electricity markets, and climatology (Hultman et al., 2007), this kind of statistical analysis has unfortunately seldom been applied to economics of nuclear liability. Understandably it can be difficult to estimate the full effects of a nuclear accident given the difficulty of placing value on human lives, health, a contaminated environment and loss of productivity. On the other hand, it is exactly for these reasons that such calculations must be attempted and more research on potential damages be developed with risks included in assessing nuclear energy viability. And if the nuclear industry is to be placed in competition with alternative sources of energy, then it is essential to understand the full weight — and cost — of its operational risks.

While the field of nuclear insurance subsidy remains considerably under-investigated, there have been a few studies conducted on the topic. The most cited are those by Dubin and Rothwell, and Heyes and Liston-Heyes. In 1990, Dubin and Rothwell were the first to estimate the value to the U.S. nuclear industry of the limitation on liability for nuclear power plants under the Price Anderson Act (PAA). No other complete study has been published in the literature since. Their underlying method was to extrapolate the premiums operators currently pay versus the full liability they would have to pay for full insurance in the absence of the PAA limits. The size of the estimated subsidy per reactor per year was $\$ 60$ million prior to the 1982 amendments, and up to \$22 million following the 1988 amendments (Dubin and Rothwell, 1990). Later in 1998 Heyes and Liston-Heyes reapplied Dubin and Rothwell's methodology adjusting the interpretation of insurance arrangements and reducing the estimates of the subsidy by a factor of ten (Heyes and Liston-Heyes, 1998). The variability in the estimate of the nuclear energy insurance subsidy is due to a fundamental assumption that the premiums for current risks are set at their "correct" levels as if someone knows what the real probability consequence is. Unfortunately, such knowledge does not exist and there have been remarkably few attempts in the academic world to narrow the uncertainty. In a separate article in 2003, Anthony Heyes updates the 1988 estimate of $\$ 22$ million per year to $\$ 33$ million (2001 dollars), and also acknowledges that as he and Liston-Heyes simply corrected the methodology of Dubin and Rothwell's study and did not introduce new variables; the true subsidy estimates could actually be even higher. Heyes goes on to say: "Do Heyes and ListonHeyes think that the true number might actually be 10 times bigger? Sure they do. Do they think that their number is closer to the truth than Dubin and Rothwell's number? No, they do not" (Heyes, 2003). In light of Heyes' comments, the figure of $\$ 33$ million per reactor per year will be used as the estimate 
Published as: I. Zelenika-Zovko and J. M. Pearce, "Diverting Indirect Subsidies from the Nuclear Industry to the Photovoltaic Industry: Energy and Economic Returns”, Energy Policy 39, pp. 2626-2632 (2011). DOI: http://dx.doi.org/10.1016/j.enpol.2011.02.031

of the value of the PAA. It should be noted that this $\$ 33$ million dollars was not escalated to $~ \$ 40$ million in 2010 dollars in order to remain conservative in light of the large potential variability of this value. While this value obviously has a large uncertainty associated with it, it is the most credible value available in academic literature to provide a baseline for this semi-quantitative comparison.

It should be noted that once any government offers this kind of an up-front insurance guarantee, it removes the incentive for the nuclear industry to look for private insurers and indebts the taxpayers with a system of continuous allotment. Trebilcock and Winter point out that such a low liability cap is also a clear disincentive to invest in safety, and in addition skews the economics of nuclear viability (1997). This is again a timely issue given that a similar liability cap (\$75 million) in off-shore drilling may have contributed to the BP Gulf of Mexico oil disaster (BP has set aside $\$ 20$ billion to correct this tragedy), which is raising concerns about liability caps, clean-up costs as well as incentives for safety (White House Press Secretary, 2010).

\section{U.S. Nuclear Energy Liability Policy}

Left with an enormous capital invested in nuclear research at the end of the WWII, and beaming with a general optimism about the future peaceful uses of atomic energy, the United States began to emphasize nuclear power as an alternative to fossil fuels (Edwards, 1997). However, before the first nuclear reactor was even constructed, it was evident that the inherent risks associated with harnessing nuclear power as a weapon would not simply disappear because its uses had now been turned to civilian purposes. Insurance agencies were unwilling to cover the full liability and indemnity for nuclear utilities as the sheer magnitude of a devastating event of a nuclear accident would likely bankrupt any company held responsible (McNeil, 2007). To resolve what was thought to be a 'temporary problem' and still encourage the development of nuclear industry, in 1957 the U.S. government legislated the Price Anderson Nuclear Industries Indemnity Act - commonly called the Price Anderson Act or PAA (United States General Accounting Office, 2004). The PAA was introduced in the hope that once the nuclear companies demonstrated a record of safe operation they would be able to obtain insurance in the private market. The insurance industry, however, did not change its view of nuclear power, and the PAA had to be renewed several times: 1966, 1967, 1969, 1975, 1977, 1988, 2002 and most recently through 2025 via the Energy Policy Act of 2005 (U.S. Department of Energy, 1999). Even today, it is well established that nuclear power is simply not insurable in the free market (Hans-Holger, 2009) and all governments have to provide some form of limited insurance liability in order for any company to consider building a reactor. The market clearly recognizes the risks and when former U.S. Vice-President Dick Cheney was asked in 2001 whether the PAA should be renewed; he was quick to respond that without the PAA "nobody's going to invest in nuclear power plants" (Reuters, 2001).

The PAA requires private operators of non-military facilities to provide a maximum primary liability of $\$ 300$ million through a private third party insurer (U.S. Department of Energy, 1999; Bradford, 2002). In case of an accident, should claims exceed this primary liability, the PAA requires all licensees to additionally provide a maximum of $\$ 95.8$ million into the accident pool - totaling roughly $\$ 10$ billion if all reactors were required to pay the maximum. While this may seem to be a large 
Published as: I. Zelenika-Zovko and J. M. Pearce, "Diverting Indirect Subsidies from the Nuclear Industry to the Photovoltaic Industry: Energy and Economic Returns”, Energy Policy 39, pp. 2626-2632 (2011). DOI: http://dx.doi.org/10.1016/j.enpol.2011.02.031

amount, it is still not sufficient in the case of a serious accident, as the cost of damages could very likely exceed the $\$ 10$ billion (U.S. Department of Energy, 1999; Reuters, 2001; Bradford, 2002). According to the PAA, should the costs of accident damages exceed the $\$ 10$ billion pool, the remainder of the costs would be fully covered by the U.S. Government. In 1982, a Sandia National Laboratories study concluded that depending on the reactor size and 'unfavorable conditions' a serious nuclear accident could lead to property damages as high as $\$ 314$ billion while fatalities could reach 50,000 (Wood, 1983). It should also be noted that under the Energy Policy Act of 2005, this accident pool of $\$ 10$ billion would not be made available immediately upon the occurrence of a nuclear accident. It would instead be accrued in retrospective payments at a maximum of $\$ 15$ million per reactor per year, leading to a 6 year delay between the initial time of the accident and the total compensation amount being made available (Koplow, 2009). While the U.S. Nuclear Regulatory Commission maintains that a probability of a nuclear accident is low, history shows this probability is none-the-less real (Three Mile Island 1979, Chernobyl 1986, and Davis-Besse 2002), and its consequences still pose a significant threat of catastrophic damages that are difficult to properly quantify. The plausibility of such an event taking place should clearly be re-evaluated, particularly given the post-9/11 global political environment. The likelihood of accident or malicious attack and the true cost of insurance also deserve renewed attention now that alternative energy methods are available and offer better return on investment with lower social and political risks.

\section{Solar PV Status and GW Manufacturing Plant Costs}

Solar photovoltaic (PV) technology is a renewable, sustainable and technically viable energy source (Pearce, 2002). PV was the fastest growing energy technology in the world for years 2006 and 2007 , encompassing 81 countries and surging to a $110 \%$ increase in market installations and a record high total of 5,559 MW produced in 2008. It continued growing even during the recession to reach 7,300 MW produced in 2009 (SolarBuzz, 2010). Coincidentally, the learning curve for the PV industry over the last 30 years has become equivalent to Moore's Law in the semiconductor industry: every doubling of cumulative PV production yields a double-digit percentage reduction in the costs of PV modules. Most studies indicate the learning rate for PV modules is approximately $20 \%$ (Schaeffer, et al., 2004; Neij, 2008), signaling that as growth continues, the day solar electricity reaches grid parity is approaching for an ever-expanding list of geographic locations and utility grids (Pinto, 2008). This growth has been particularly impressive in " $2^{\text {nd }}$ generation" thin film PV production, which grew by $123 \%$ in 2008 to reach $0.89 \mathrm{GW}$ in total (SolarBuzz, 2009).

The growth of thin film PV is directly linked to improvements within the industry itself. First, there are improvements of technical knowledge, such as a clear understanding of the nature of protocrystallinity in amorphous, nanocrystalline, and microcrystalline silicon materials as well as the concomitant solar cells (Collins, 2003; Ferlauto, et al., 2004). This scientific understanding improves module performance and thus increases the output for a given production line (for example, more MW/year with the same capital equipment investment). Second, according to VLSI Research, a key trend for the last year in the PV industry was the 'rise of the turnkey thin-film line' (VLSI Research Inc., 2009). These turnkey manufacturing plants (also known as fabricators or "fabs") allow for a 
Published as: I. Zelenika-Zovko and J. M. Pearce, "Diverting Indirect Subsidies from the Nuclear Industry to the Photovoltaic Industry: Energy and Economic Returns”, Energy Policy 39, pp. 2626-2632 (2011). DOI: http://dx.doi.org/10.1016/j.enpol.2011.02.031

multiplication effect in production capacity (Keshner and Arya, 2004). The key advantage that provides a multiplication effect to thin film amorphous silicon-based solar turnkey solutions is that they are supported by large multinational corporations with established track records of success in both the semiconductor and equipment manufacturing industries. Supplying turnkey manufacturing solutions reduces ramp up time, allows for the rapid technology transfer, employs best practices and greatly expands the PV production rate (velocity) as opposed to several new manufacturing companies starting out on their own. With a large fab (GW/year-size), even a single manufacturing plant of thin film PV can reach grid parity (Keshner and Arya, 2004; Pearce, 2008), thus electricity fed on to the grid by the PV would cost the same or less than from other current sources. To purchase a $1 \mathrm{GW} / \mathrm{year}$ thin film solar photovoltaic turnkey fab would cost about $\$ 2$ per W/yr (Weinzerl, 2009). Accounting for the infrastructure (building, gas supply/handling equipment, land etc.) will add another approximately $\$ 400$ million for a total cost of $\$ 2.4$ billion for a $1 \mathrm{GW} /$ year plant (Weinzerl, 2009).

\section{Analysis of the Indirect Subsidy Transfer}

If an indirect subsidy worth US $\$ 33$ million per reactor/year was transferred from the nuclear industry (for insurance liability capping) to solar PV (for a manufacturing loan guarantee), it would need to be accrued for 73 years to purchase a $1 \mathrm{GW} / \mathrm{yr}$ solar PV fabrication facility at approximately $\$ 2.4$ billion. In order to observe a rapid increase in PV deployment and accurately compare the energy output between the two industries provided with the same indirect subsidy, it is assumed that the nuclear insurance subsidy from all 104 U.S. NPPs is transferred to PV manufacturing in the first year and every year nuclear reactors are in operation. As U.S. nuclear reactors go out of service and are not replaced, the subsidy becomes unavailable for further loan guarantees for additional PV fabs. Data on nuclear life expectancy and subsequent subsidy transfer to solar PV is based on the information provided by the United States Nuclear Regulatory Commission database containing a comprehensive list of all operating reactors and their projected license expiry dates (United States Nuclear Regulatory Commission, 2010). Since each NPP is roughly $1 \mathrm{GW}$ of capacity, it can be assumed that the insurance subsidy is $\$ 33$ million per GW NPP/year. The total power of the nuclear ensemble for the U.S. at any given time $(\mathrm{t})$ is given by:

$$
\mathrm{P}_{N T}(\mathrm{t})=\mathrm{P}_{N} \times \mathrm{N}(\mathrm{t})
$$

where $\mathrm{N}$ is the number of NPPs operating in that year $t$ and the $\mathrm{P}_{\mathrm{N}}$ is given as $1 \mathrm{GW}$. The number of 1 GW PV manufacturing plants (PV fabs) funded by a shift of the indirect nuclear insurance subsidy in the U.S. is given by:

$$
\mathrm{F}_{P V}(\mathrm{t})=\left(\mathrm{P}_{N T}(\mathrm{t}) \times \mathrm{S}_{I}\right) / \mathrm{C}_{P V} \quad[\# \text { of } 1 \mathrm{GW} \text { PV fabs }]
$$

where $S_{I}$ is the indirect subsidy per nuclear power plant ( $\$ 33$ million/GW (NPP)/year) and $C_{\mathrm{PV}}$ is the cost of a $1 \mathrm{GW}$ PV thin film fab. The capacity of PV arrays deployed in any year $\mathrm{t}$ is simply:

$$
\mathrm{P}_{P V}(\mathrm{t})=\mathrm{F}_{P V}(\mathrm{t}-1) \quad[\mathrm{GW}]
$$


Published as: I. Zelenika-Zovko and J. M. Pearce, "Diverting Indirect Subsidies from the Nuclear Industry to the Photovoltaic Industry: Energy and Economic Returns”, Energy Policy 39, pp. 2626-2632 (2011). DOI: http://dx.doi.org/10.1016/j.enpol.2011.02.031

in order to account for the 1 year delay to fabricate and install panels after the PV plant has been commissioned. Given the enormous growth of the PV market (Solarbuzz, 2010), and the fact that such a thin film PV GW/year factory would produce modules competitive with the least expensive on the market (Keshner and Arya, 2004; Pearce, 2008), it can be assumed that the demand will outpace the actual production. Thus, here it is assumed that the entire capacity of the PV plant can be absorbed by the market, based on such a plant being able to sell PV at prices that place the cost of solar electricity at grid parity or better. The cumulative PV power available from the U.S. indirect nuclear energy insurance shifting to $\mathrm{PV}$ is given by the addition of the new $\mathrm{PV}$ power, $\mathrm{P}_{\text {new, }}$ and the previously accumulated installed (old) PV power, $\mathrm{P}_{\text {old }}$, multiplied by the degradation factor (D) of the PV modules :

$$
P_{P V T}(t)=P_{\text {new }}+D * P_{\text {old }}=P_{P V}(t)+D * \sum\left(P_{P V}(t-1)\right)[\mathrm{GW}]
$$

The degradation factor is 0.99 , assuming a $1 \%$ per year degradation rate of the PV panels (Skoczek et al., 2009). This again is a conservative estimate as the likely degradation rate will be less. For simplicity, the cost of money, energy, and inflation are ignored. It was assumed that the NPP is in operation $90 \%\left(U_{N}\right)$ of the time (a reasonable assumption from past performance (EIA, 2009)), allowing for routine maintenance, and producing roughly four times more energy per unit power than a photovoltaic array. To estimate the amount of energy produced by the photovoltaic ensemble, 5 sun hours/day (or $21 \%$ utilization $\left[\mathrm{U}_{\mathrm{PV}}\right]$ ) was chosen for illustrative purposes, assuming that the PV arrays would be deployed in favorable geographic locations such as the U.S. southwest.

\section{Results of Indirect Subsidy Transfer in the U.S.}

Results of a policy shift to reinvest an indirect insurance subsidy from 104 nuclear reactors to loan guarantees for large scale solar photovoltaic fabrication can be seen in Figures 1 and 2. It should be clarified here that the decreasing number of nuclear plants seen in Figure 1 and 2 is simply the normal retirement schedule assuming no new nuclear power plants are built. If more nuclear plants were commissioned then the value of the indirect subsidies made available to transfer to PV are larger. This analysis is a comparison of the efficacy of similarly valued indirect subsidies. 
Published as: I. Zelenika-Zovko and J. M. Pearce, "Diverting Indirect Subsidies from the Nuclear Industry to the Photovoltaic Industry: Energy and Economic Returns", Energy Policy 39, pp. 2626-2632 (2011). DOI: http://dx.doi.org/10.1016/j.enpol.2011.02.031

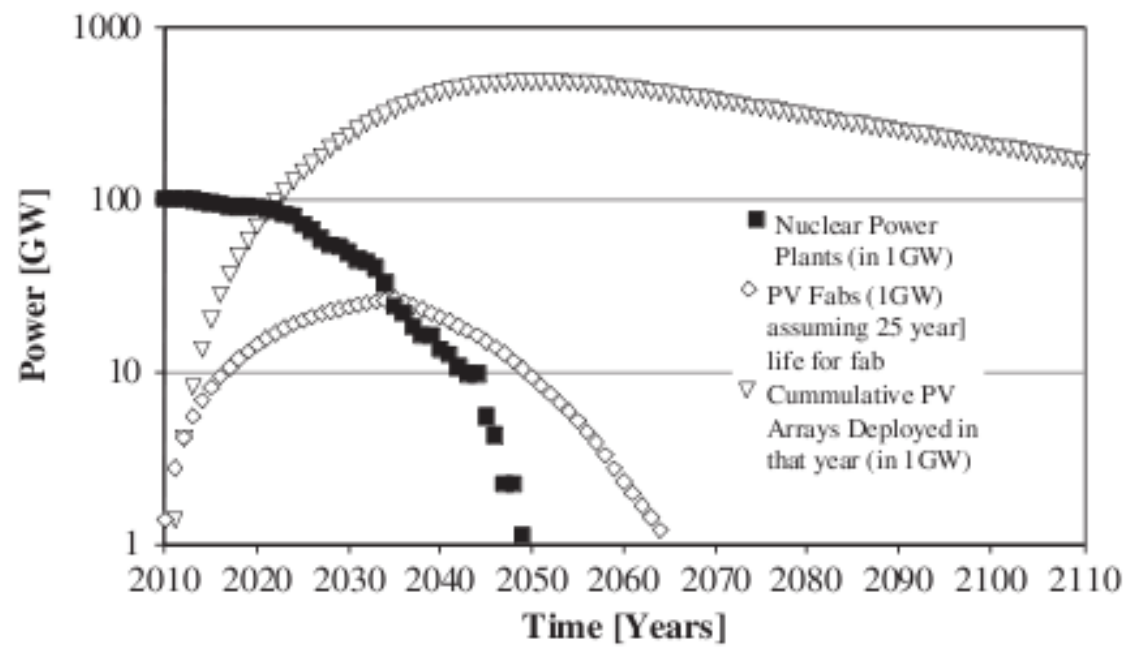

Figure 1. Comparison of power [GW] funded by identical indirect subsidies for the nuclear and PV industry in the U.S.

Figure 1 illustrates the magnitude of power from PV arrays deployed by the large scale PV manufacturing facilities. It should be noted that for clarity the y-axis is shown in log scale. It is assumed that society no longer invests any additional funds in new NPPs as has been the trend in the last quarter century. Thus as can be seen in Figure 1, the squares representing NPPs decrease as they are retired from service. As seen in the Figure 1, the number of $1 \mathrm{GW}$ PV fabs (diamonds) increases according to the number of nuclear reactors in operation and nuclear insurance subsidy reinvested. The PV fabs are given a 25 year life expectancy and thus their total number also eventually decline. Once PV fabs reach their peak numbers around 2035, the aggressive increase of the cumulative PV arrays (triangles) deployed levels off and starts to go down with the relatively small degradation rate of $1 \%$ per year in performance as assumed before. However, the drop is gradual because of course all the fabs constructed in previous years are still producing hundreds of MW of PV cells each year. The PV arrays financed for a particular year are not counted in until the following year when they would be fully operational.

While deployment of PV fabs and arrays is a preliminary measure of the energy potential, the most important number to compare is in the cumulative energy over time as the two technologies as they have different utilization rates. Illustrated in Figure 2, cumulative energy produced by nuclear reactors (filled squares) is plotted with the cumulative energy produced by solar PV arrays (open diamonds) from 2010 for 100 years. 
Published as: I. Zelenika-Zovko and J. M. Pearce, "Diverting Indirect Subsidies from the Nuclear Industry to the Photovoltaic Industry: Energy and Economic Returns", Energy Policy 39, pp. 2626-2632 (2011). DOI: http://dx.doi.org/10.1016/j.enpol.2011.02.031

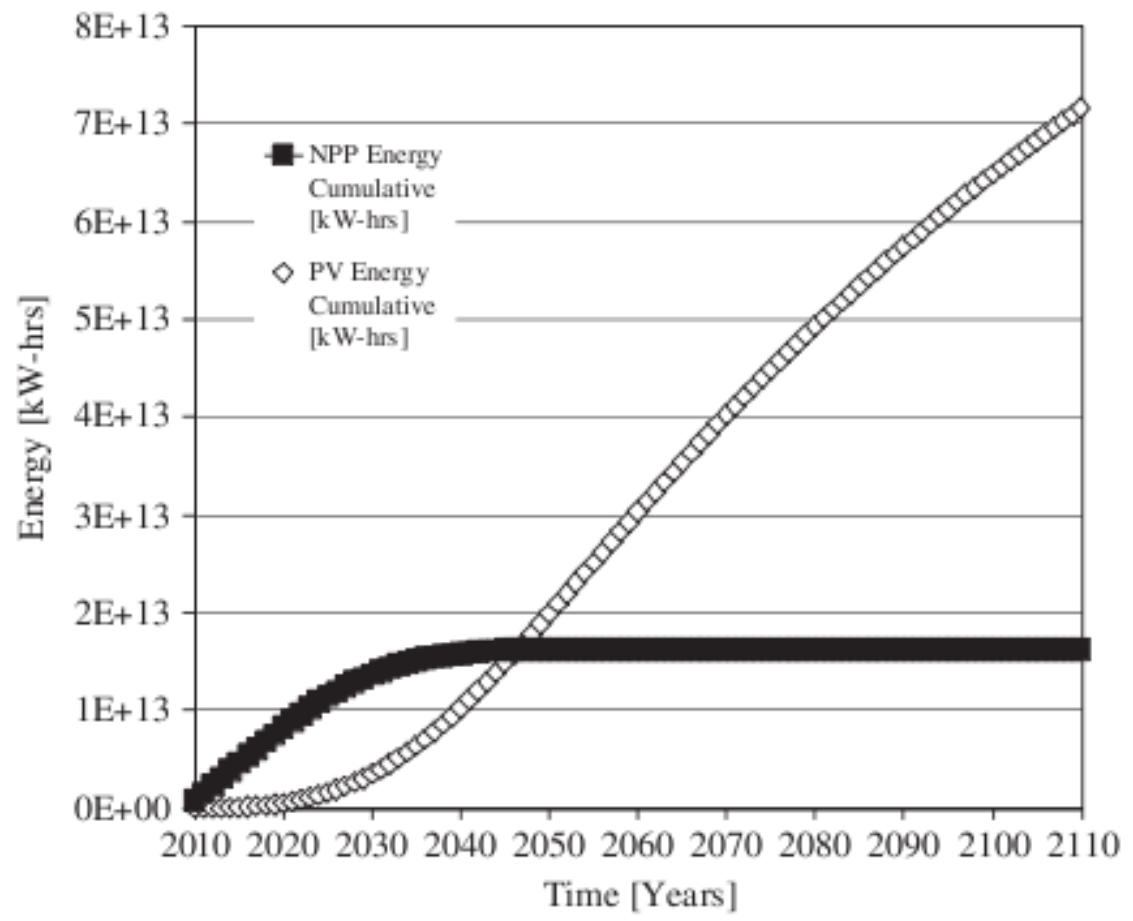

Figure 2. Cumulative U.S. energy production comparison of nuclear and PV funded by equal indirect subsidies

Initially while all 104 nuclear reactors are still in service, their current $\$ 33$ million per reactor insurance subsidy is also made available to the solar industry resulting in roughly $\$ 3.4$ billion for the investment in solar PV fabs. The transfer results in approximately 14 new $100 \mathrm{MW}$ fabs each deploying PV arrays totaling $1.39 \mathrm{GW}$ for the first three years. Naturally with time, the number of new PV fabs introduced each year starts to decrease as more and more nuclear reactors go off line (though such an assumption is only made for purposes of the comparison calculated by this study; naturally, a government may want to continue loan guarantees for even more solar PV fabs). However the cumulative potential of the PV arrays deployed in all the previous years is still producing electricity with minimal degradation to the panels. The point where the two data sets intersect (year 2046) is when both technologies have amassed an equal amount of cumulative energy for that year of $1.63 \times 10^{13} \mathrm{~kW}$-hrs and when solar PV starts to produce more. As the last nuclear reactor is shut down in the year 2050, the nuclear cumulative output stops entirely at $1.63 \times 10^{13} \mathrm{~kW}$-hrs. By contrast solar arrays continue to produce electricity in an amount rising to $1.99 \times 10^{13} \mathrm{~kW}$-hrs. By 2080 solar arrays produce an additional $2.94 \times 10^{13} \mathrm{~kW}$-hrs, and, should they remain in operation until the end of the $21^{\text {st }}$ century, the potential PV cumulative electricity output amounts to $6.49 \times 10^{13} \mathrm{~kW}$-hrs. Compared to the nuclear power output, this roughly translates to an additional 48,600 TW-hrs $\left(6.49 \times 10^{13}-1.63 \times 10^{13} \mathrm{~kW}\right.$-hrs $)$ of electricity produced by solar PV in 2110 if an indirect subsidy transfer were to take place. The potential of solar PV is truly amazing; put in financial terms, as current U.S. national average cost of electricity is about $\$ 0.11 / \mathrm{kW}$-hr (Energy 
Published as: I. Zelenika-Zovko and J. M. Pearce, "Diverting Indirect Subsidies from the Nuclear Industry to the Photovoltaic Industry: Energy and Economic Returns”, Energy Policy 39, pp. 2626-2632 (2011). DOI: http://dx.doi.org/10.1016/j.enpol.2011.02.031

Information Administration, 2010), the extra 48,600 TW-hrs of energy would be worth 5.3 trillion dollars. By the year 2110, the money now slated for nuclear insurance premiums in the U.S. could produce an additional $\$ 5.3$ trillion if invested in solar PV loan guarantees. It should be noted here that it is difficult to compare the value of electricity produced by nuclear and PV as they provide for different loads. However, as time of use pricing and smart metering become more refined this analysis can be reexamined. Similarly estimation of potential cumulative electricity output by any energy source for the next 100 years is extremely challenging and Figure 2 should be viewed primarily for likely trends given the most realistic assumptions available currently.

While many new and emerging industries are subsidized by governments in order to help them penetrate the market, the nuclear industry is not a new technology. It is clear from the preceding results that the indirect subsidy provided to the nuclear industry in the U.S. is better spent on solar photovoltaic technology. These results have showcased the energy return potential of just one indirect subsidy to solar PV and makes it clear that tens of billions of dollars of direct funding already spent on the nuclear sector would be better utilized from an energy perspective if invested in PV. Just as a point of reference, in 2000, the Renewable Energy Policy Project concluded that from 1943 through 1999, cumulative federal subsidies to electricity generating technologies (excluding hydro-power) totaled approximately $\$ 151$ billion (Goldberg, 2000). Of that funding, the nuclear industry received $\$ 145.4$ billion (or over $96 \%$ ) while wind received $\$ 1.3$ billion and photovoltaic and solar thermal power shared a total of only $\$ 4.4$ billion (Goldberg, 2000). In 2009 the U.S. Congress appropriated $\$ 1.317$ billion for nuclear research and development (up $\$ 284$ million from 2008), setting aside an additional $\$ 18.5$ billion in loan guarantees for new nuclear power plants as well as $\$ 2$ billion for uranium enrichment (Holt, 2009). Despite such generous funding, the nuclear industry is not competitive or efficient in the open markets. For the nuclear industry, subsidies have simply hidden the real costs of power generation and perpetuated many false benefits largely responsible for current hopes of a 'nuclear renaissance'.

\section{Limitations and Future Work}

Although this semi-quantitative study consists of best data available, given that a robust up-todate study on nuclear insurance subsidy has not yet been funded, the calculations and value estimates shown here are limited. Such a study would be evolving with time as the costs associated with a nuclear accident or a terrorist attack on a nuclear facility are constantly increasing. Recent estimates for the 1986 Chernobyl accident cite Ukraine's losses of $\$ 130$ billion and Belarus cites losses of $\$ 35$ billion (BBC News, 1998). In case of a substantial nuclear disaster, current assumed market costs of insurance would also increase and so would the corresponding values for the indirect subsidy. In such an instance, the limit placed upon the nuclear industry liability would change as well as the methods of risk quantification and the variables based largely on the probability of the accident/terrorist attack. In addition to the assumptions surrounding the liability limits of nuclear power, other variables such as the number of available sun hours, learning curves, advances in technology for both PV and nuclear energy, deployment logistics, much more fine-tuned risk assessments, inflation, and energy price escalation should be investigated in the future. In particular the simplifying assumption to ignore the cost of 
Published as: I. Zelenika-Zovko and J. M. Pearce, "Diverting Indirect Subsidies from the Nuclear Industry to the Photovoltaic Industry: Energy and Economic Returns”, Energy Policy 39, pp. 2626-2632 (2011). DOI: http://dx.doi.org/10.1016/j.enpol.2011.02.031

capital, or the discount rate, can significantly skew the results over long time frames involved in the productive lives of these energy assets. Clearly the cost of a given kiloWatt hour of electricity is not going to remain constant over the life cycle of a PV device and the results provided here are simply meant to be illustrative.

It should also be pointed out here that one of the major assumptions in this paper is that large scale conventional thin film PV manufacturing having been made possible with a loan guarantee will achieve economies of scale to the point that the demand for low cost PV enables the factories to sell all of their production. The reasoning behind this assumption is outlined in section 5, and PV produced and sold at a large scale provides one of the few geographically unconstrained sources of inexpensive renewable energy. However, from a policy perspective, it may be necessary to provide some other form of support to ensure that the market can absorb the full production. This support can be modeled off of programs already in existence throughout the world and take the form of i) direct investment subsidies where the authorities refund part of the installation cost of PV system, iia) Feed-in Tariffs, where the electricity utility buys PV electricity from the owner of the PV system under a multi-year contract at a guaranteed rate(s) or iib) net metering where the price paid by the utility for PV generated electricity is the same as the price charged as electricity produced by a PV system in excess of the amount being used by the owner of the system is fed into the grid, and iii) Solar Renewable Energy Certificates (SREC) where a PV electricity production or consumption target is set, and the utility is obliged to purchase the PV electricity or face an Alternative Compliance Payment. All of these forms of support can be administered in such a way as to be technically neutral in the PV field so that a market mechanism chooses the best PV technology.

In general this analysis tried to err on the side of conservative estimates, however, in one area the impact could be vastly underestimated. The indirect subsidies investigated here (nuclear insurance and loan guarantees for PV fabs) are notionally equivalent because a loan guarantee is only called on when the fab fails to repay its lenders, just as a federal payout in the nuclear case only happens in the event of a major nuclear catastrophe. The existence of a federal loan guarantee may not only make investment in large scale $(>\mathrm{GW}) \mathrm{PV}$ fabs possible at an earlier date in the U.S., but also presumably lowers the cost of borrowed funds to the fabs owners further driving down the cost of PV. Due to the nature of loan guarantees, companies can improve the weighted average cost of capital for their projects by many percentage points. Similarly the notional equivalent to the annual implicit subsidy in not having to buy catastrophic insurance in the nuclear case. Future work is needed to estimate the value of the loan guarantee to equate to the dollar amount of the estimated insurance premium subsidy (e.g. calculate the implicit value of the loan guarantee to see how much the cost of capital to build a PV fab is lowered). This has been done in the case of loan guarantees for nuclear power plants (Stone, 2009) and could be applied to the PV manufacturing case. Thus the equivalent indirect subsidy to the nuclear insurance subsidy would not be the value of the subsidy itself, but instead the total amount of annual guaranteed borrowing needed under a large-scale PV ramp up multiplied by the interest rate reduction that comes from a federal guarantee. This line of reasoning would create a much larger PV power output and energy output per given indirect subsidy transfer. Finally, it should be noted that the choice to compare solar PV was made in a large part to data availability for the costs of the necessary scale of 
Published as: I. Zelenika-Zovko and J. M. Pearce, "Diverting Indirect Subsidies from the Nuclear Industry to the Photovoltaic Industry: Energy and Economic Returns”, Energy Policy 39, pp. 2626-2632 (2011). DOI: http://dx.doi.org/10.1016/j.enpol.2011.02.031

manufacturing. A similar analysis could be performed in the future with other renewable energy sources (e.g. solar thermal, wind, geothermal, etc.), which may be even more promising use of the current nuclear energy indirect subsidy.

While no guarantee can be made that the subsidy value estimates used here are exact, the energy results speak for themselves and serve as an excellent point of reference for comparative policy options. It is, of course, acknowledged that nuclear and PV facilities provide different abilities to be dispatched and would be integrated into a distributed grid in different ways, however, it is clear that far more electricity is made available over the life cycle by indirect subsidies for PV than is made available through indirect subsidy for nuclear. Even under limited values assumed for the Price Anderson Act and the conservative sun hour exposure numbers used above, it is evident that a considerable revenue is made possible by the additional PV generated electricity, revenues that can only grow as the PV manufacturing plant prices continue to decrease (and more PV fabs can be deployed for the same transfer of nuclear indirect subsidies). The overall energy output and the financial returns examined in this paper call for a further investigation of nuclear liability values as well as the need to reevaluate current energy policies.

\section{Conclusions}

In this study, the potential power, energy and financial returns were quantified in order to compare the efficacy of the indirect subsidy that is currently provided to the U.S. nuclear industry in the form of liability caps and free government insurance, with the efficacy of providing the same level of indirect subsidy to the solar photovoltaic manufacturing industry in the form of loan guarantees. Based on a proposed policy shift where an equivalent indirect subsidy of approximately $\$ 33$ million per reactor per year is transposed from U.S. nuclear industry for insurance into a loan guarantee for PV manufacturing, the overall energy output of solar PV and nuclear were found over the life cycle. The startling results show that even if just this one relatively minor and often-ignored subsidy was diverted from nuclear power generation into large scale PV manufacturing, it would result in both more installed power and more energy produced by mid-century. It is worth emphasizing here that this comparison simply ignores all the other subsidies to nuclear power. Such a policy would increase the cumulative PV industry over the $5.35 \times 10^{11} \mathrm{~kW}$-hrs (or $535 \mathrm{TW}$-hrs) mark in just ten years and surpass cumulative nuclear energy production in under 40 years. By the end of the 100 years the cumulative electricity output of solar amounts to an additional 48,600 TW-hrs over the nuclear case, which at the current U.S. national average cost of electricity is amounts to $\$ 5.3$ trillion.

The results of this study clearly show that both indirect and direct subsidy transfers from the nuclear to photovoltaic industry results in more power and energy over the life cycle of the technologies. In light of these results and with the recent economic challenges, climate destabilization, and a newfound emphasis on sustainability, U.S. energy policy needs to re-evaluate its options and appropriate available funds wisely by moving away from nuclear power and diversifying their energy portfolio to maximize the renewable (not alternative) energy potential. 
Published as: I. Zelenika-Zovko and J. M. Pearce, "Diverting Indirect Subsidies from the Nuclear Industry to the Photovoltaic Industry: Energy and Economic Returns”, Energy Policy 39, pp. 2626-2632 (2011). DOI: http://dx.doi.org/10.1016/j.enpol.2011.02.031

\section{Acknowledgments}

The authors would like to acknowledge helpful discussions with K. Branker, R. Andrews, B. Purchase, and T. Carpenter and support of the the Natural Sciences and Engineering Research Council of Canada.

\section{References}

Atomic Energy Canada Limited, 2009. Canada is Ready to Ride the Nuclear Renaissance Wave. AECL News Room. Accessed 1 March, 2010. Available at http://www.aecl.ca/NewsRoom/News/Press2009/090513.htm

Barnham, K. W. J., Mazzer, M., and Clive, B. 2006. Resolving the energy crisis: nuclear or photovoltaics?, Nature Materials 5, 161 - 164.

BBC News. 1998. Neighbours count cost of Chernobyl disaster, BBC News, Sunday, 26 April, 1998.

Blackburn, J. and Cunningham, S. 2010. Solar and Nuclear Costs - The Historic Crossover: Solar Energy is Now the Better Buy. NC WARN: Waste Awareness \& Reduction Network. Accessed 20 August, 2010. Available at: http://www.ncwarn.org/wp-content/uploads/2010/07/NCW-SolarReport final1.pdf

Bradford, P. A. 2002. Renewal of the Price Anderson Act, Testimony before the United States Senate Committee on Environment and Public Works Subcommittee on Transportation, Infrastructure and Nuclear Safety, January 23, 2002.

Branker, K., and Pearce, J.M. 2010. Financial return for government support of large-scale thin-film solar photovoltaic manufacturing in Canada. Energy Policy, 38 (8), pp. 4291-4303.

Bouw, B. 'Nuclear renaissance' sparks clamour for uranium. The Globe and Mail, Feb. 05, 2010.

Brown, G. J. 2006. Point: Nuclear power is cheap and reliable. The Eagle Tribune. September 24, 2006.

Collins, R.W., Ferlauto, A.S., Ferreira, G.M., Chen, C., Koh, J., Koval, R.J., Lee, Y., Pearce, J.M., and Wronski., C. R. 2003. Evolution of microstructure and phase in amorphous, protocrystalline, and microcrystalline silicon studied by real time spectroscopic ellipsometry, Solar Energy Materials and Solar Cells 78(1-4),143-180.

Cooper, M. 2009. All Risk, No Reward for Taxpayers and Ratepayers: The Economics of Subsidizing the 'Nuclear Renaissance' with Loan Guarantees and Construction Work in Progress, Report of the Institute for Energy and the Environment, Vermont Law School. Available at http://www.nirs.org/neconomics/110309cooperreport.pdf 
Published as: I. Zelenika-Zovko and J. M. Pearce, "Diverting Indirect Subsidies from the Nuclear Industry to the Photovoltaic Industry: Energy and Economic Returns”, Energy Policy 39, pp. 2626-2632 (2011). DOI: http://dx.doi.org/10.1016/j.enpol.2011.02.031

Deutch, J. M., Forsberg, C. W., Kadak, A. C., Kazimi, M. S., Moniz, E. J., Ansolabehere, J. E., Du, Y. and Pierpoint, L. 2009. Update of the MIT 2003 Future of Nuclear Power: An Interdisciplinary MIT Study. Massachusetts Institute of Technology, Cambridge.

Dubin, J. A. and Rothwell, G. S. 1990. Subsidy to Nuclear-Power through Price-Anderson Liability Limit, Contemporary Policy Issues, 8, 73-79.

Edwards, G. 1997. The Historical Origins of Canada's Nuclear Liability Act. Canada's Coalition for Nuclear Responsibility.

Energy Information Administration. 2010. Energy Information Administration. 2009. Average Retail Price of Electricity to Ultimate Customers by End-Use Sector, by State. Electric Power Monthly: Data for November 2009. Accessed 1 March, 2010. http://www.eia.doe.gov/cneaf/electricity/epm/table5 6 a.html

Etzkowitz, H. 1984. Solar versus Nuclear Energy: Autonomous or Dependent Technology? Society for the Study of Social Problems, 31(4), pp. 417-434.

Ferlauto, A.S., Ferreira, G.M., Koval, R.J., Pearce, J.M., Wronski, C.R., Collins, R.W., Al- Jassim, M.M., Jones, K.M., 2004. Evaluation of compositional depth profiles in mixed phase (amorphous+ crystalline) silicon films from real time spectroscopic ellipsometry. Thin Solid Films 455-456, 665669.

Fthenakis, V.M. and Kim, H.C. 2007. Greenhouse-gas emissions from solar electric- and nuclear power: A life-cycle study, Energy Policy, 35, 2549-2557.

Goldberg, M. 2000. Federal energy subsidies: not all technologies are created equal. Research Report No. 11. Renewable Energy Policy Project, Washington, DC. Accessed 1 March, 2010. Available at www.repp.org/repp pubs/pdf/subsidies.pdf

Hans-Holger, R. 2009. Carbon Free Energy, presented at $2^{\text {nd }}$ Canadian Climate Change Technology Conference, Hamilton, Canada.

Heyes, A. 2003. Determining the Price of Price-Anderson, Regulation, 25(4), 105-110.

Heyes, A. G. and Liston-Heyes, C., 1998. Subsidy to nuclear power through Price-Anderson liability limit: comment, Contemporary Economic Policy 16, 122-124.

Heyes, A. G. and Liston-Heyes, C. 2000. An empirical analysis of the Nuclear Liability Act (1970) in Canada, Resource and Energy Economics 22, 91-101. 
Published as: I. Zelenika-Zovko and J. M. Pearce, "Diverting Indirect Subsidies from the Nuclear Industry to the Photovoltaic Industry: Energy and Economic Returns”, Energy Policy 39, pp. 2626-2632 (2011). DOI: http://dx.doi.org/10.1016/j.enpol.2011.02.031

Hoffert, M. I., Caldeira, K., Benford, G., Criswell, D. R., Green, C., Herzog, H., Jain, A. K., Kheshgi, H. S., Lackner, K. S., Lewis, J. S., Lightfoot, H. D., Manheimer, W., Mankins, J. C., Mauel,M. E., Perkins, L. J., Schlesinger, M. E., Volk, T. and Wigley, T. M. L. 2002. Advanced Technology Paths to Global Climate Stability: Energy for a Greenhouse Planet, Science, 298, pp. 981-987.

Holt, M. 2008. CRS Report for Congress- Nuclear Energy Policy, November 2008. Accessed 1 March, 2010. Available at http://www.fas.org/sgp/crs/misc/RL33558.pdf

Hultman, N. E., Koomey, J. G., and Kammen, D. M. 2007. What History Can Teach Us about the Future Costs of U.S. Nuclear Power, Environmental Science and Technology. 41(7), pp. 2087-2094.

Intergovernmental Panel on Climate Change (IPCC), 2008. Climate Change 2007: Synthesis Report. Intergovernmental Panel on Climate Change. Cambridge University Press: Cambridge, United Kingdom.

International Energy Agency (IEA) 2010. Energy Subsidies: Getting the Prices Right. Office of the Chief Economist.. Accessed 11 December, 2009. Available at http://www.worldenergyoutlook.org/docs/energy subsidies.pdf

Kammen, D. M., and Pacca, S. 2004. Assessing the costs of electricity, Annual Review of Environment and Resources 29, 301-344.

Kenny, R., Law, C., and Pearce, J.M. 2010. “Towards Real Energy Economics: Energy Policy Driven by Life-Cycle Carbon Emission”, Energy Policy 38, pp. 1969-1978

Keshner, M.S. and Arya, R. 2004. "Study of potential cost reductions resulting from super-large-scale manufacturing of PV modules”, National Renewable Energy Laboratory final subcontract report, NREL/SR-520-36846.

Koplow, D. 2009. Nuclear Power as a Taxpayer Patronage: A Case Study of Subsidies to Calvert Cliffs Unit 3. Nonproliferation Policy Education Center.

Kutscher, C.F. (editor), 2007. Tackling Climate Change in the U.S. Tackling Climate Change in the U.S. Potential Carbon Emissions Reductions Efficiency and Carbon Emissions Reductions from Energy Efficiency and Renewable Energy by 2030’, American Solar Energy Society.

Ling, K. 2010. Can Fresh Funds Jump-Start a U.S. Nuclear Renaissance? Scientific American. February 16, 2010.

Legislative Assembly of Ontario. 2009. Bill 150: First Reading. The Green Energy Act 2009. Printed by the Legislative Assembly of Ontario.

http://www.ontla.on.ca/bills/bills-files/39 Parliament/Session1/b150.pdf 
Published as: I. Zelenika-Zovko and J. M. Pearce, "Diverting Indirect Subsidies from the Nuclear Industry to the Photovoltaic Industry: Energy and Economic Returns”, Energy Policy 39, pp. 2626-2632 (2011). DOI: http://dx.doi.org/10.1016/j.enpol.2011.02.031

McLellan, D. 2008. NEF Paper No. 1: The Economics of Nuclear Power: Current Debates and Issues for Future Consideration. The Centre for International Governance Innovation. The Nuclear Energy Futures Project.

McNeil, B., 2007. The Costs of Introducing Nuclear Power to Australia, Journal of Australian Political Economy 59, 5-29.

Neij, L., 2008. Cost development of future technologies for power generation-a study based on experience curves and complementary bottom-up assessments, Energy Policy 36(6), 2200-2211.

Pearce, J. M. 2002. Photovoltaics - A Path to Sustainable Futures, Futures 34(7), 663-674.

Pearce, J. M. 2008a. Thermodynamic Limitations to Nuclear Energy Deployment as a Greenhouse Gas Mitigation Technology, International Journal of Nuclear Governance, Economy and Ecology 2(1), 113130.

Pearce, J. M. 2008b. Industrial Symbiosis for Very Large Scale Photovoltaic Manufacturing, Renewable Energy 33, 1101-1108.

Pinto, M. R. 2008. Has the sun finally risen on photovoltaics?, 2008 Symposium on VLSI Technology, 2-5.

Reuters, 2001. “Cheney says push needed to boost nuclear power”, Reuters News Service, May 15, 2001.

Schaeffer G. J. 2004. Learning from the Sun; Analysis of the use of experience curves for energy policy purposes-The case of photovoltaic power", Final report of the Photex project, DEGO: ECN-C04-035.

Sharma, H.D. 1990. (Editor) Energy Alternatives: Benefits and Risks, Symposium on the Risks and Benefits of Energy Alternatives Institute for Risk Research, University of Waterloo Press: Waterloo, ON.

Skoczek, A., Sample, T. and Dunlop, E.D. 2009. The Results of Performance Measurements of Fieldaged Crystalline Silicon Photovoltaic Modules, Progress in Photovoltaics: Research and Applications, 17(4), $227-240$.

Slavin, M. 2009. The Federal Energy Subsidy Scorecard: How Renewables Stack Up, Renewable Energy World. November 3, 2009.

SolarBuzz, 2009. "Solarbuzz Reports World Solar Photovoltaic Market Grew to 5.95 Gigawatts in 2008”, World PV Industry Report Summary, Accessed 11 June, 2010. Available:

http://www.solarbuzz.com/Marketbuzz2009-intro.htm 
Published as: I. Zelenika-Zovko and J. M. Pearce, "Diverting Indirect Subsidies from the Nuclear Industry to the Photovoltaic Industry:

Energy and Economic Returns”, Energy Policy 39, pp. 2626-2632 (2011). DOI: http://dx.doi.org/10.1016/j.enpol.2011.02.031

SolarBuzz, 2010. Solarbuzz Reports World Solar Photovoltaic Market Grew to 7.3 Gigawatt in 2009, Accessed 11 June, 2010. Available at http://www.solarbuzz.com/marketbuzz2010-intro.htm

Stone, B. K. 2009. Using Fair Return Prices to Assess the Value and Cost of Financial

Guarantees for Nuclear Power Plants, International Law and Management

Review 6 (Winter 2009), 83-110.

Tokarick, S. 1996. Export promotion: the role of transportation subsidies, Journal of Economic Studies. 23 (4), 50-63.

Trebilcock, M. and Winter, R.A. 1997. The Economics of Nuclear Accident Law, International Review of Law and Economics, 17(2), 215-243.

United States General Accounting Office, 2004. Nuclear Regulation: NRC's Liability for Nuclear Power Plants Owned by Limited Liability Companies, Report to Congressional Requesters.

United States Nuclear Regulatory Commission, 1983. The Price-Anderson Act: the Third Decade, NUREG-0957.

United States Nuclear Regulatory Commission. 2002. Reactor License Renewal: Preparing for Tomorrow's Safety Today, NUREG/R-0291.

United States Nuclear Regulatory Commission. 2010. Operating Nuclear Power Reactors by Location or Name. Facility Info Finder. Accessed June 1, 2010. http://www.nrc.gov/info-finder/reactor/

U.S. Department of Energy. 1999. Department of Energy Report to Congress on the Price-Anderson Act, Prepared by the U.S. Department of Energy, Office of General Council. Accessed 20 August 2010. Available: http://www.gc.energy.gov/documents/paa-rep.pdf

VLSI Research Inc., 2009. Photovoltaic cell manufacturing equipment:Top-10 supplier ranking. VLSI Research, Bedford, England. Accessed 20 August 2010. Available: https://www.vlsiresearch.com/public/cms pdf upload/pdf file 1233694471.pdf

Weinzerl, H., 2009. Personal Communication. Oerlikon Solar Americas, Oerlikon Solar USA, Inc January 18, 2009.

White House Office of the Press Secretary, 2010. Statement by President Barack Obama. Briefing Room, Released May 18, 2010. Accessed 20 August 2010. Available:

http://www.whitehouse.gov/the-press-office/statement-president-obama-oil-liability

Wood, W.C. 1983. Nuclear Safety; Risks and Regulation. American Enterprise Institute for Public Policy Research, Washington, D.C. pp. 40-48. 
Published as: I. Zelenika-Zovko and J. M. Pearce, "Diverting Indirect Subsidies from the Nuclear Industry to the Photovoltaic Industry:

Energy and Economic Returns", Energy Policy 39, pp. 2626-2632 (2011). DOI: http://dx.doi.org/10.1016/j.enpol.2011.02.031

World Energy Council. 2004. Energy Data Centre: Global Energy Scenarios to 2050 and Beyond. UN World Energy Council. Accessed 1 March, 2010. Available: http://www.worldenergy.org/wecgeis/edc/scenario.asp

World Nuclear Association. 2009. Civil Liability for Nuclear Damage Report. World Nuclear Association. Accessed 1 March, 2010. Available: http://www.world-nuclear.org/info/inf67.html 